\title{
NON-DESTRUCTIVE ANALYSES OF COPPER ALLOYS AND SILVER ITEMS FROM VOITENKI. THE RECYCLING OF METAL IN CHERNIAKHOV CULTURE
}

\author{
MIKHAIL V. LIUBICHEV, ${ }^{1}$ OLEKSANDR M. BUHAY, ${ }^{2}$ \\ ERDMUTE SCHULTZE ${ }^{3 *}$
}

\begin{abstract}
${ }^{1}$ Teaching and Research Laboratory of the Germanic-Slavonic Archaeological Expedition at Kharkiv National V.N. Karazin University, Svobody Square 6, Kharkiv, 61022, Ukraine ${ }^{2}$ Centre for Collective Use 'Accelerated Mass Spectrometry' Institute of Applied Physics, NAS of Ukraine, Sumy 58 Petropavlivska St, Ukraine

${ }^{3 *}$ Former staff member in the Eurasia Department of the German Archaeological Institute, Podbielskiallee 69-71, 14195 Berlin, Germany
\end{abstract}

\section{Keywords}

Non-destructive analyses, Pixe, Cherniakhov culture, metal working, recycling of metal

\begin{abstract}
Brooches, belt buckles and other metal objects with a specific design are considered characteristic of Cherniakhov culture. In contrast with well-known typologies, the metal composition of these objects has rarely been investigated. Forty-four artefacts from the settlement and cemetery at Voitenki (east Ukraine) were chosen for metal analysis. The fibulae selected, for example, consist of crossbow tendril brooches, crossbow brooches with a closed catch-plate, brooches with a high catch-plate, and other types. A total of 38 finds were made of non-ferrous metal; for six objects, silver was presumed. The precise metal composition was determined by PIXE (particle-induced $\mathrm{X}$-ray emission) analysis. Based on this method, copper, bronze and brass could be determined as material for the brooches and buckles. The bronze objects were divided into forged bronze and cast bronze; furthermore, mixed material was detected. But these groups and subgroups of metal do not coincide with archaeological types. Crossbow tendril brooches were first of all made of copper, although some consist of bronze or brass. Cast bronze was used for manufacturing some cast types of brooches. The producer probably intentionally selected this material to cast. But on the other hand, it seems that the producer used the material that was available, for example, cast bronze for forged brooches. For silver finds, the PIXE analysis detected a high content of this metal. A comparison of the results with analyses of Roman silver denarii led us to the hypothesis that such Roman coins were used as 'raw material' for manufacturing these silver items.
\end{abstract}

\section{Introduction}

Non-ferrous and silver artefacts are known from many sites of Cherniakhov culture in the northern Black Sea region. The form and design of jewellery, tools and other metal objects mostly indicate domestic manufacturing; whereas the raw material for copper alloys and silver was not produced by local craftsmen. Similar to other regions in the European Barbaricum, metal objects from the Roman Empire, like metal vessels and coins, were used as material. As products of highly developed Roman metal working, the material of these objects often had a different composition and a specific quality. Obviously, the crafts- men of Cherniakhov culture successfully treated this varying 'raw material'. But it is not clear how much they knew about the different character of Roman metal artefacts, and if they were able to use this knowledge deliberately for their own metal working. In order to answer these questions, and to evaluate the standard of metal working, the natural scientific analysis of metal objects is required. For Central Europe, the investigation by Hans-Ulrich Voß, Peter Hammer and Joachim Lutz (1998) should be mentioned, where Roman and Germanic objects of nonferrous and precious metal were compared. As a result, six groups of alloys for copper have been detected, some of them useful for forging, others for casting. The specialists

*Corresponding author. E-mail: erdmute.schultze@dainst.de 


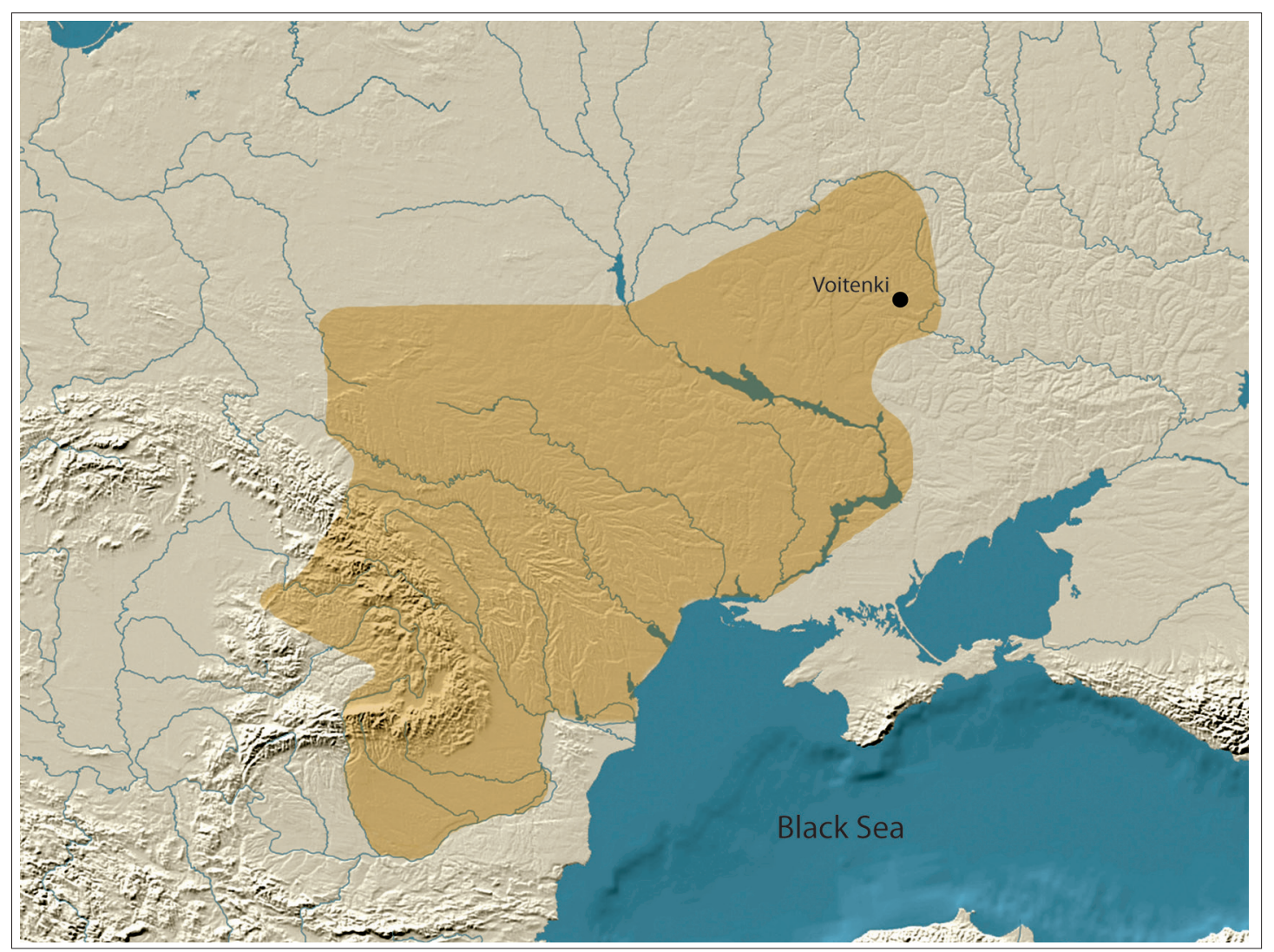

Figure 1. The area of Cherniakhov culture in the 4th century AD, with the location of Voitenki (compiled by A. Kaeselitz, Berlin).

came to the conclusion that Roman and Germanic craftsmen worked with non-ferrous alloys according to the specific character of each alloy (Voß et al. 1998, pp. 276-284).

But for Cherniakhov culture, there are only a few former investigations regarding non-ferrous metal artefacts. In 1972, Evgeniy Nikolaevich Chernykh and Tatyana Borisovna Bartseva studied 623 non-ferrous metal objects deriving from 34 sites by spectral analysis (Chernykh and Bartseva 1970). During the last few years, a number of coins, namely barbarian copies or imitations of Roman coins, were analysed with PIXE (Particle-Induced X-Ray Emission). The numismatists Alexander Bursche and Kirill Myzgin (2017) connect these coins, mostly found in west Ukraine and Moldova, with the activities of Cherniakhov culture.

To learn more about the general level of metal working in this culture, we started analyses of metal objects from Voitenki in 2016 as a pilot study. The investigation was conducted as cooperation between the Institute of Applied Physics in the NAS of the Ukraine in Sumy, the Faculty of History of the National V.N. Karazin University in Kharkiv, and the Eurasia Department of the German Archaeological Institute in Berlin. The study included objects made of iron, non-ferrous and precious metal. The first results were presented by the authors (Liubichev et al.
2020). The results for non-ferrous and precious metals are discussed here.

The village of Voitenki ${ }^{1}$ is situated in eastern Ukraine, approximately 50 kilometres west of Kharkiv. In Roman times, the history of settlement in this site started in the second half of the 3rd century AD with the horizon of Boromlia. Then, from the first decades of the 4th century until the beginning of the 5th century, the site was part of Cherniakhov culture (Fig. 1). The archaeological complex consists of a cemetery and a corresponding settlement of at least 17 hectares. In 2004, the Germanic-Slavonic Archaeological Expedition of the National Karazin University in Kharkiv started investigations, which are still going on now. Several buildings, settlement pits and four pottery kilns in the settlement came to light. Most of the features belong to Cherniakhov culture. Only a few remains of a settlement dating from the horizon of Boromlia were discovered in sector A of the site. In the area of the cemetery, 262 graves of Cherniakhov culture had been excavated by 2020, including 137 cremation graves, 123 inhumation graves, and two cenotaphs. The abundant finds consist of ceramics, metal, bones, glass and several other materials. Numerous metal finds were detected on the surface, in the layers and features of the settlement and the cemetery.

\footnotetext{
1 The site is known in research literature as Voitenki, the Russian name of the village. Its modern Ukrainian name is Viitenky.
} 
The pilot study of non-ferrous and precious metal included the analysis of 44 artefacts. Of them, 38 objects consisted of non-ferrous metal, usually called 'bronze'. Six objects were made of 'white' metal, supposedly silver. Therefore, the following questions determined the approach of our investigation:

- Traditionally, many fibulae and belt buckles are described as bronze; but it has to be checked if they really are made of bronze, or consist of copper alloy and other alloying elements, for example zinc.

- Bronze includes different mixtures of copper and tin, often with further components. As was mentioned above, in the Barbaricum, local metal objects were made from copper alloy of Roman origin. Therefore, quite a different composition can be expected for bronze artefacts. But could there have been a specific mixture, typical only of Voitenki? Or can differences concerning the metal for groups of objects be determined, a specific composition for certain types of objects?

- 'White' metal is usually considered to be silver, but this conclusion should be checked; further analysis should determine the quality of the metal.

\section{Review of the finds}

The 38 objects of non-ferrous metal consist of 21 fibulae and 17 belt buckles (Figs. 2 and 3). It has to be mentioned that one fibula (No 270) does not derive from Voitenki, but was found during a survey on the Cherniakhov culture settlement in Gvozdevo, about 16 kilometres to the west. Fifteen of the artefacts from Voitenki are stray finds, nine were detected in layers of the settlement or the cemetery, and 13 objects were discovered in graves.

Among the 21 brooches, nine originate from undisturbed graves. Three fibulae (Fig. 2.71-73) were part of the inventory of grave 129: a pair of uniform fibulae, and a single brooch. The selection of fibulae for analysis includes different typological groups and types. The biggest group, as generally in this site, consists of ten crossbow tendril brooches, otherwise specified as crossbow fibulae with an upturned foot (Fig. 2.69-78). According to the typological system of Oskar Almgren (1923), these brooches belong to his group VI.1. In the classification of Evgeniu L. Gorokhovskiu (1989), these brooches are connected with his series B. Seven crossbow fibulae have a closed catchplate of quite a different form (Fig. 2.79-85). They represent Almgren group VI.2. The fragment of a cast brooch was identified as a knop bow fibula (Bügelknopffibel) (Fig. 2.88). The fibula from grave 183 does not coincide with only one type, but contains elements of a sheet brooch (Blechfibel) and a knop bow fibula (Fig. 2.89). All the brooches mentioned so far are connected with Cherniakhov culture, and are dated to the 4 th century AD. The previous horizon of Boromlia is represented by two damaged fibulae, whose feet with a high catch-plate are preserved (Fig. 2.86, 87). They belong to Almgren group VII, and are dated to the second half of the 3rd century AD.

From the selected 17 belt buckles, 12 finds came from the cemetery, of which five were recorded in undisturbed graves. Most of the frames of the buckles are thickened and oval-shaped (Fig. 3.90-94), only a few frames are round without thickening (Fig. 3.105-106). The frame of the buckle from grave 161 features faceted ornamentation (Fig. 3.104). The preserved pins often have a thickened base, some with a metope (Fig. 3.100, 102-103). Some buckles have a rectangular, rounded or oval-shaped ferrule (Fig. 3.100-102). According to the existing classifications for belt buckles, the finds from Voitenki correspond to group H of Renata Madyda-Legutko (1987), or series V, G, D (V, G, D) of Gorokhovskiı (1989). All the samples are connected with Cherniakhov culture.

Six 'white' metal objects were chosen for analysis; four of them originated from the settlement. A small fragment was discovered in the layer (Fig. 4.107). Another fragment (Fig. 4.108), supposedly part of a pendant, and later a thickened oval-shaped ring, a pendant or frame of a buckle (Fig. 4.111), was found on the surface of the settlement. An elongated pendant of sheet metal was recorded in construction 2 of settlement part A (Fig. 4.109). A wire ring with coiled ends derives from the layer of the cemetery (Fig. 4.110). Boris V. Magomedov (2001, pp. 71-72) noted analogies of such rings from several cemeteries of Cherniakhov culture. He mentioned silver rings from graveyards in Kurniki (grave 17), Sântana de Mureş (graves 47, 63), and Tîrgşor (grave 43). In grave 17 at Kurniki, as many as seven bronze and one silver ring were discovered above the shoulders of a buried child (Magomedov 1999, p. 111, Figs. 11 and 12.19), presumably part of hair decoration.

The sixth artefact at Voitenki made of 'white'/silver metal came from grave 144 . The inventory consisted of four fittings and a ring with a suspension loop (Fig. 4). The fittings are made of strips of sheet; the strips are bent lengthwise to form a U-shaped cross-section. On one side, the edges of the sheets are decorated with a punched line. The fittings are slightly curved, and together they form a circle of about 12.2 centimetres in diameter. They were fixed by six straight metal strips overlapping the tuber-like fittings. Their extended ends are connected by a rivet for attaching the fittings. A silver ring of tetragonal cross-section was probably also part of the construction. A loop in the form of an omega is suspended from the ring. Obviously, the fittings were originally wrapped over the rim of a vessel. It was probably made of wood, but due to the small size of merely 3.1 millimetres between the two edges of the 


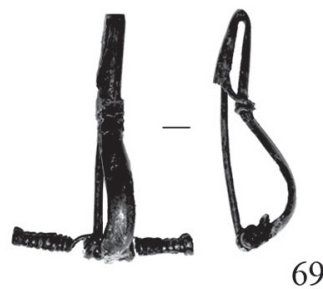

69
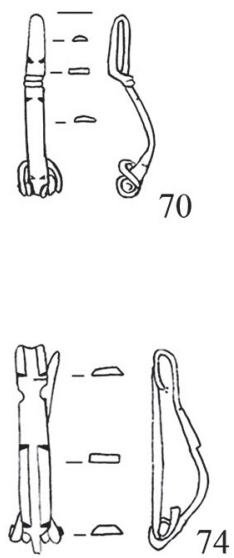

73

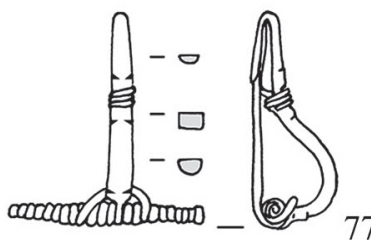

77
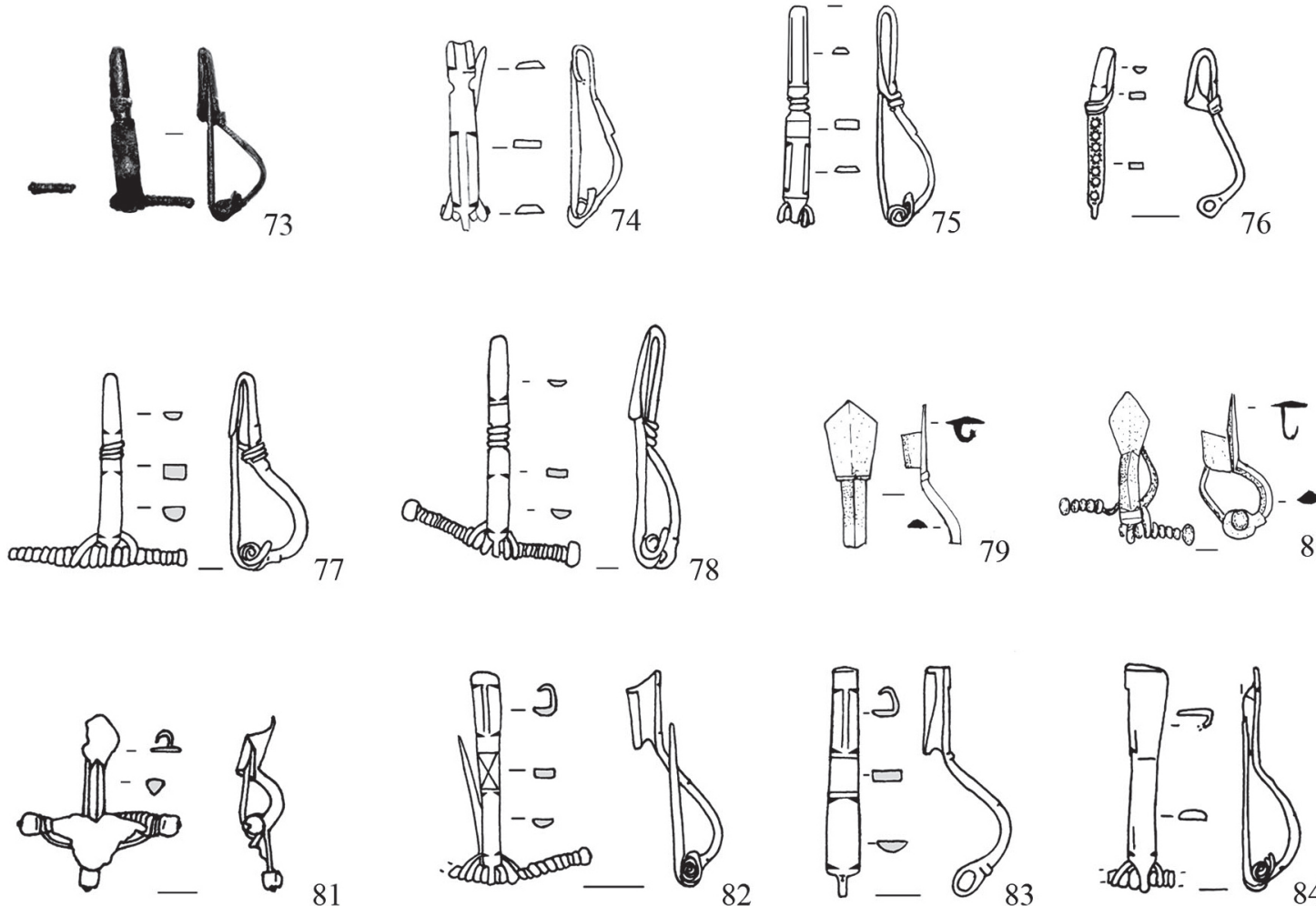

82
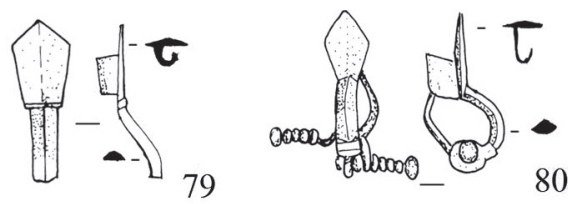
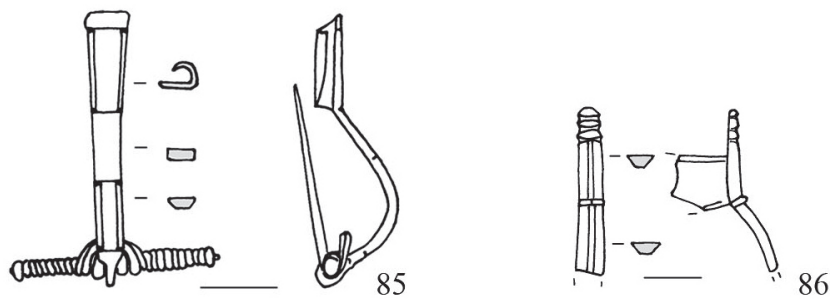

85
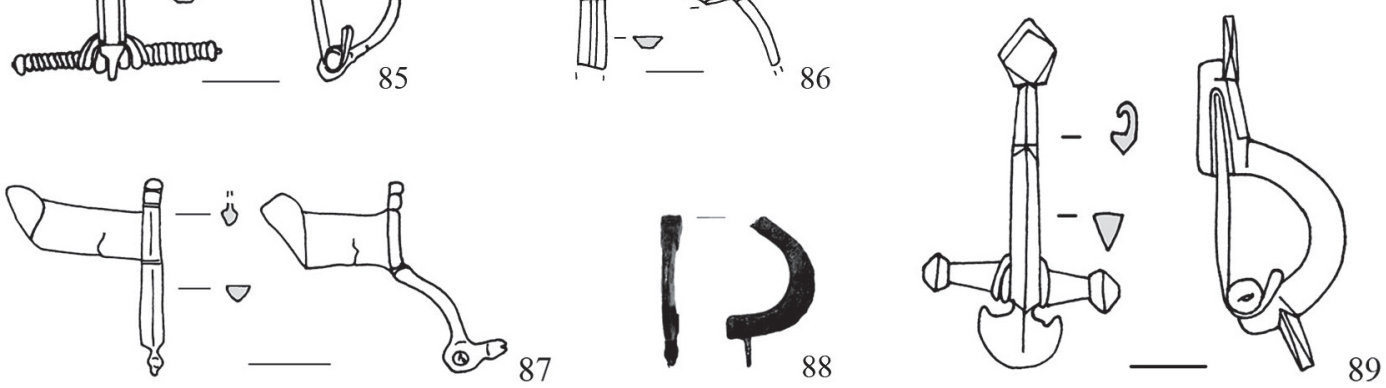

Figure 2. Fibulae from Voitenki and Gvozdevo: 69 grave 127; 70 stray find; 71-73 grave 129; 74, 79, 80, 82 settlement layer; 75 grave $141 ; 76,83,86-88$ stray finds; 77 grave 177; 78, 81 cemetery layer; 84 grave 118; 85 grave 186; 89 grave 183 (based on material from the Germanic-Slavonic Archaeological Expedition, Kharkiv). 


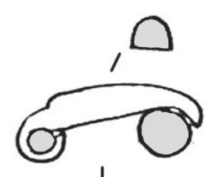

1

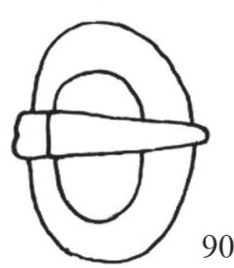

90
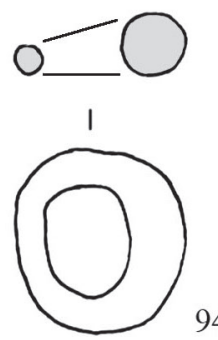

94

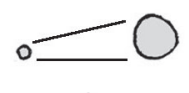

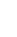

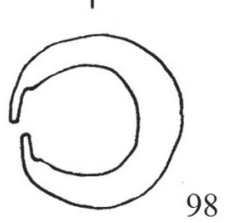

98
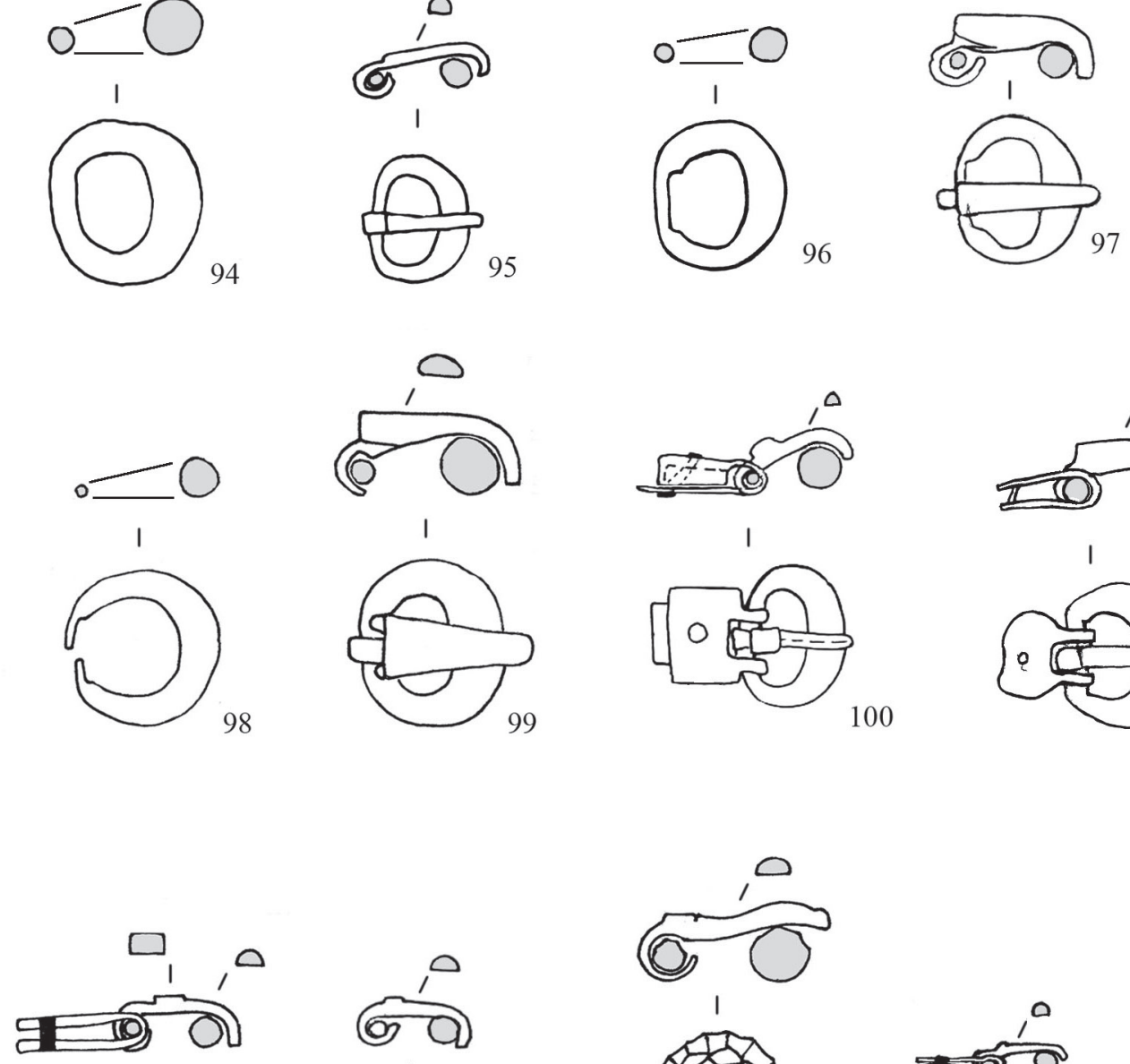

100
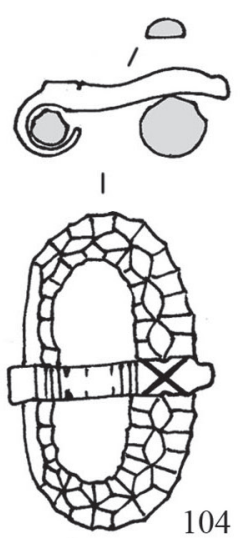

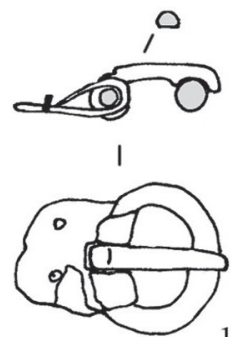

106

Figure 3. Belt buckles from Voitenki: 90 settlement layer; 91 grave 117; 92 grave 125; 93 grave 124; 94-96, 98-100, 102 stray finds; 97, 103, 105, 106 cemetery layer; 101 grave 127; 104 grave 161 (based on material from the Germanic-Slavonic Archaeological Expedition, Kharkiv). 

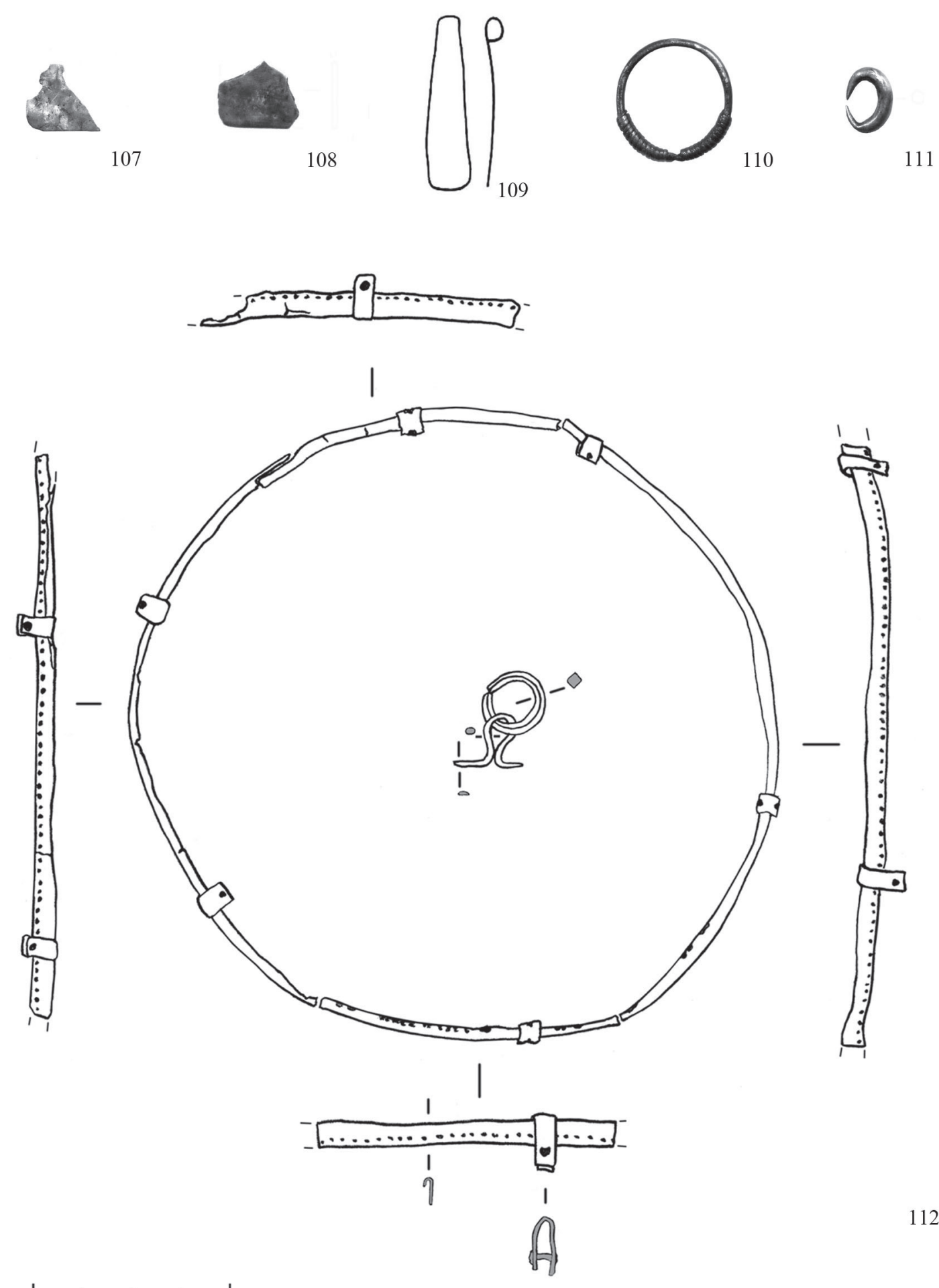

Figure 4. Silver items from Voitenki: 107 settlement layer; 108, 111 stray finds; 109 settlement, construction 2; 110 cemetery, layer; 112 grave 144 (based on material from the Germanic-Slavonic Archaeological Expedition, Kharkiv). 


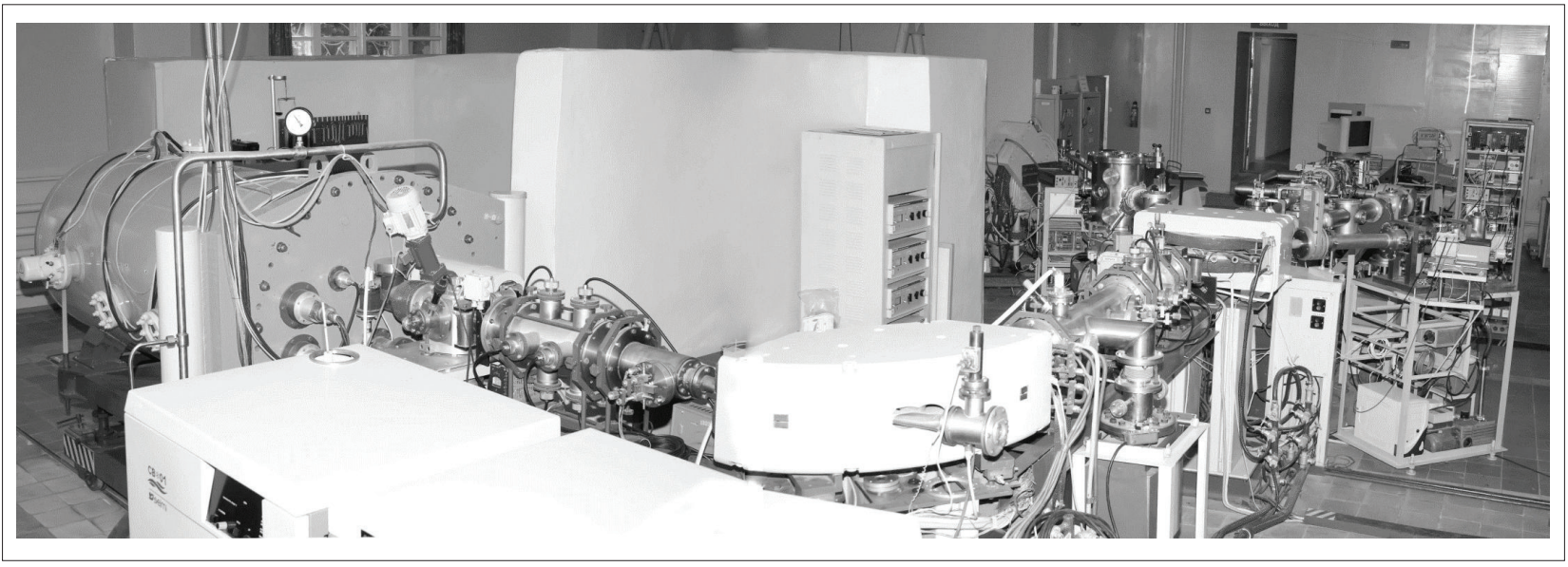

Figure 5. Analytical complex on the basis of $2 \mathrm{MeV}$ electrostatic accelerator, IAP NAS of Ukraine, Sumy (archive of IAP NAS of Ukraine, Sumy).

fittings, other materials like leather or horn could also be taken into account.

Within the area of Cherniakhov culture, only one analogy for such silver fittings is known. In the cemetery at Cherneliv Ruskiy, in the Ternopol region, three silver fittings with strips were discovered in grave 298 (Gereta 2016, pp. 89-90, Fig. 150.11-12, 15-16). Further silver fittings are known from wooden buckets in Central Europe, where such vessels always occurred in inhumation burials together with other objects of silver or precious metal. As a prominent example, the publication of the grave at Gommern, Germany, should be mentioned. Matthias Becker (2010, Table $21.4 ; 22.2 ; 36.1-5)$ succeeded in reconstructing three wooden vessels there, including one with silver fittings wrapped over the rim. This inventory is dated to the second half of the 3rd century AD. A special paper recently presented further analogies of 'princely graves' with silver fittings from this period, and discussed these inhumations in comparison with cremation grave 144 at Voitenki (Schultze and Liubichev 2020).

\section{Method of research}

The metal samples were analysed at the Analytical Accelerator Complex of the Institute of Applied Physics of the National Academy of Sciences of Ukraine (Sumy) (Fig. 5 ), by particle-induced X-ray emission (PIXE) (Buhay et al. 2015). With the specified technique applied, a proton beam with $1 \mathrm{MeV}$ and 3-13 nA current is guided from the accelerator into the scattering chamber, then through the one-millimetre collimator orifice it gets perpendicularly on to the sample surface (Fig. 6). To stop secondary electrons, emission-blocking electrodes are used (Fig. 6.3).

Characteristic X-rays (Fig. 6.7) are detected by an Amptek XR100 - SDD detector (9) placed at an angle of $45^{\circ}$ to the sample surface. A filter (Fig. 6.8) is used to absorb highintensity low-energy lines, which negatively affect the detector dead time and hence measurement accuracy. A combination of two 45-millimetre polyethylene-terephthalate films and $20 \mu \mathrm{m}$ aluminum foil placed between them is used as a filter. The filter almost entirely removes the light element lines from the spectra obtained, in particular the silicon lines, from which energy is absorbed by aluminium as much as possible. The rotating holder (Fig. 6.6) enables the analysis of up to 12 samples in a session. The measurement of an accumulated charge at the sample surface is crucial for quantitative PIXE analysis. We used current-conducting carbon and copper duct tapes to remove the charge. The surface charge was measured with a current integrator. For higher accuracy in the elemental analysis of unknown samples, standard samples of gold and clay of known composition ISE 9521 were used. The elemental concentration from the obtained spectra was calculated with GUPIX software (Campbell et al. 2000) (Fig. 7). Each sample was measured three times. The results obtained were averaged. The components of the complex objects were analysed separately from each other.

Principal component analysis (PCA) was used to identify patterns in data and highlight their similarities and differences. Principal component analysis is a dimensionality-reduction method that is used to reduce the dimensionality of large data sets, by transforming a large set of variables into a smaller one that still contains most of the information in the large set. The elemental content of samples was used to perform PCA.

\section{Results}

Fibulae. The fibulae studied are grouped by their chemical content under the classification given in Tables 1-3: 

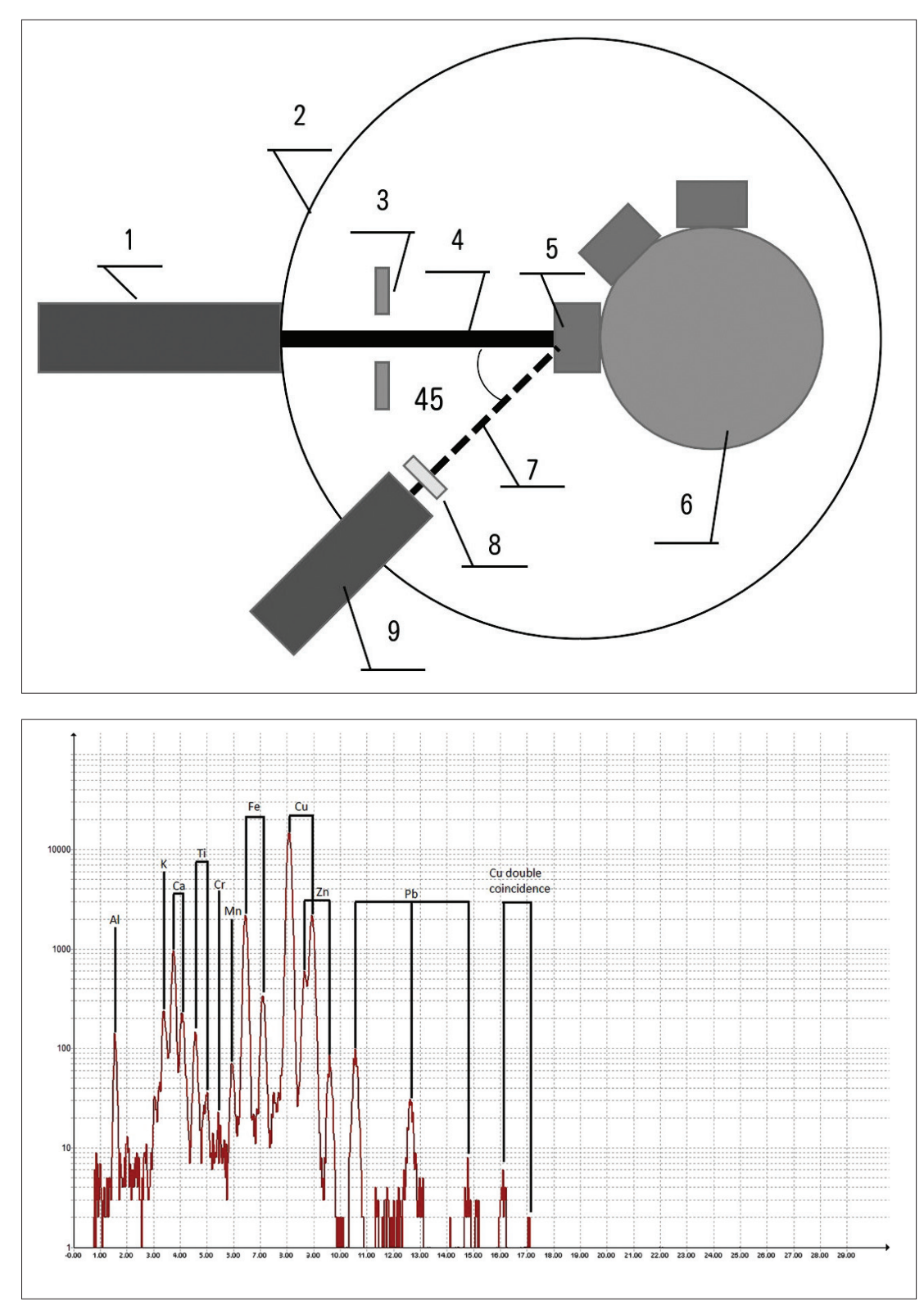

Figure 6. Schema of the scattering chamber for the PIXE analysis: 1 . ion guide; 2 . chamber; 3 . blocking electrode; 4. proton beamline; 5 . sample;

6. rotating sample holder; 7. X-ray; 8. filter; 9. X-ray detector (IAP NAS of Ukraine, Sumy).

Figure 7. Typical X-ray spectrum from (IAP NAS of Ukraine, Sumy).
1) copper $(\mathrm{C})$; 2) forged bronze (FB); 3$)$ tin bronze (TB); 4) cast bronze $(\mathrm{CB})$; 5) brass $(\mathrm{B})$; 6) mixed bronze (MB). PCA was also applied for the fibulae to allow the automated search for regularities between separate data (for example, to find samples of a similar composition and to show their correlation with other samples) by cutting data dimension by reducing the data to the principal components, PC1, PC2, PC3, etc, with minimal data loss (Figs. 8 and 9). Among the fibulae, copper ones prevail (Table 1). Slight admixtures of zinc, tin and lead are observed, up to $3 \%$ wt. In samples $75,78,80$ and 87 , silver was also found. In fibulae 73 and 80 , and in one part of fibula 72 , tin was completely absent. Sample 87 had the highest concentration of silver, $1.6 \mathrm{wt} \%$ compared to the other fibulae from all groups. Table 2 presents samples classified as forged, cast and mixed bronze. Not a single sample material was classified as tin bronze. The tin content in these samples varied from 0.6 to $59 \mathrm{wt} \%$. The minimal amount of tin is observed in sample 79, which belongs to the mixed bronze group, but had the most analytical ambiguous result, as its aluminium content was $21.49 \mathrm{wt} \%$.

Such a high concentration of aluminium may indicate that this sample contained a large amount of aluminosilicate slag, which was also evidenced by high concentrations of calcium, potassium, titanium, strontium and iron. In our opinion, the classification of fibula 86 was also ambiguous. Formally, in terms of the numerical values of the element concentrations (mainly for zinc), it belonged to the group of mixed bronzes, but the high concentration of lead will definitely cause a significant decrease in the melting temperature, which is typical of cast bronze. Since the ion beam cross-section applied in PIXE is of some millimetres, the analysis could have been performed in a location where zinc was segregated through various diffusion processes and its concentration was high. Therefore, it would be more reasonable to attribute sample 86 to the 


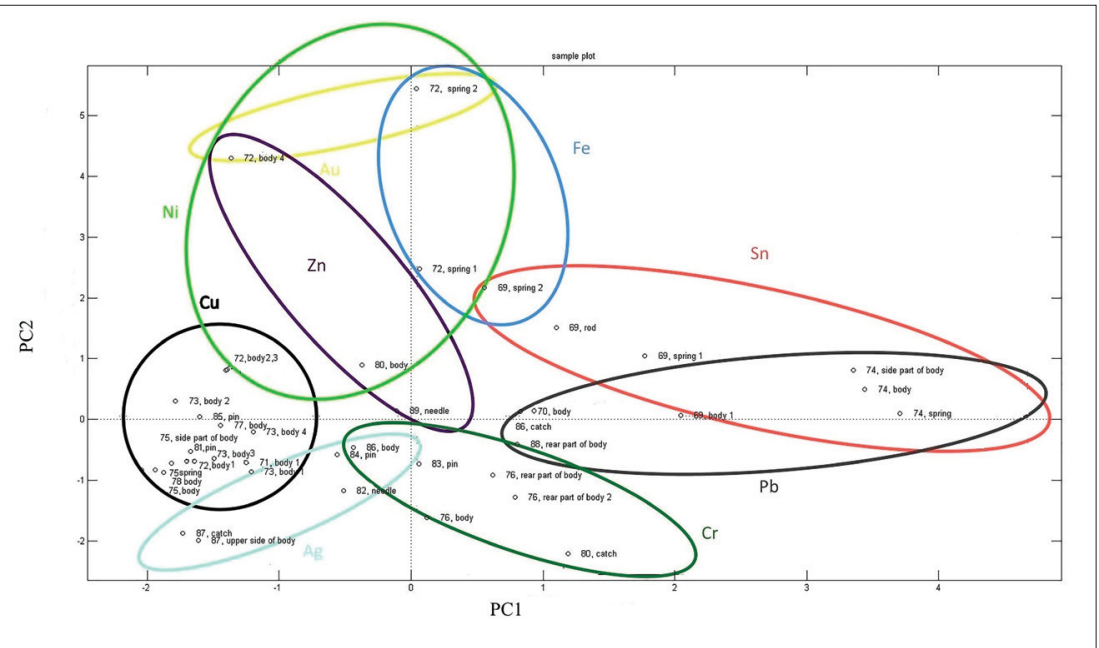

Figure 8. Principal component analysis of fibulae (IAP NAS of Ukraine, Sumy).

Table 1. The chemical composition of copper fibulae (concentration in wt \%).

\begin{tabular}{|c|c|c|c|c|c|c|c|}
\hline & Fibula 75 & Fibula 76 & Fibula 78 & Fibula 87 & Fibula 80 & Fibula 73 & Fibula 72.1 \\
\hline $\mathrm{Al}$ & $\mathrm{ND}$ & $\mathrm{ND}$ & $\mathrm{ND}$ & 0.628 & 4.663 & $\mathrm{ND}$ & $\mathrm{ND}$ \\
\hline $\mathrm{Cl}$ & $\mathrm{ND}$ & $\mathrm{ND}$ & $\mathrm{ND}$ & $\mathrm{ND}$ & $\mathrm{ND}$ & 2.287 & 2.19 \\
\hline $\mathrm{K}$ & 0.099 & 0.375 & 0.009 & $\mathrm{ND}$ & 0.349 & 0.679 & 0.228 \\
\hline $\mathrm{Ca}$ & 0.211 & 1.492 & 0.052 & 0.323 & 1.882 & 0.802 & 0.322 \\
\hline $\mathrm{Sc}$ & 0.009 & 0.029 & 0.002 & 0.007 & 0.071 & $\mathrm{ND}$ & $\mathrm{ND}$ \\
\hline $\mathrm{Ti}$ & 0.015 & 0.073 & 0.002 & 0.012 & 0.04 & 0.064 & 0.01 \\
\hline $\mathrm{V}$ & $\mathrm{ND}$ & 0.003 & 0.008 & 0.023 & 0.073 & $\mathrm{ND}$ & 0.004 \\
\hline $\mathrm{Cr}$ & 0.001 & 0.026 & $\mathrm{ND}$ & 0.006 & 0.012 & 0.003 & $\mathrm{ND}$ \\
\hline $\mathrm{Mn}$ & 0.002 & 0.05 & 0.001 & 0.002 & 0.009 & $\mathrm{ND}$ & $\mathrm{ND}$ \\
\hline $\mathrm{Fe}$ & 0.226 & 0.762 & 0.187 & 0.294 & 0.392 & 0.467 & 0.301 \\
\hline $\mathrm{Co}$ & 0.003 & 0.009 & 0.004 & 0.008 & 0.005 & 0.008 & 0.009 \\
\hline $\mathrm{Ni}$ & 0.005 & $\mathrm{ND}$ & 0.006 & 0.008 & 0.435 & 0.027 & 0.024 \\
\hline $\mathrm{Cu}$ & 96.193 & 94.287 & 97.327 & 90.228 & 83.796 & 92.987 & 91.6 \\
\hline $\mathrm{Zn}$ & 1.406 & 0.419 & 2.126 & 1.951 & 2.44 & 1.743 & 2.621 \\
\hline $\mathrm{As}$ & 0.056 & 0.374 & 0.011 & 0.07 & 0.539 & $\mathrm{ND}$ & $\mathrm{ND}$ \\
\hline $\mathrm{Sr}$ & $\mathrm{ND}$ & 0.057 & 0.017 & $\mathrm{ND}$ & $\mathrm{ND}$ & $\mathrm{ND}$ & $\mathrm{ND}$ \\
\hline $\mathrm{Ag}$ & 0.075 & $\mathrm{ND}$ & 0.048 & 1.606 & 0.17 & $\mathrm{ND}$ & $\mathrm{ND}$ \\
\hline $\mathrm{Cd}$ & $\mathrm{ND}$ & $\mathrm{ND}$ & $\mathrm{ND}$ & $\mathrm{ND}$ & $\mathrm{ND}$ & $\mathrm{ND}$ & $\mathrm{ND}$ \\
\hline $\mathrm{Sn}$ & 1.161 & 1.866 & 0.125 & 3.03 & $\mathrm{ND}$ & $\mathrm{ND}$ & $\mathrm{ND}$ \\
\hline $\mathrm{Au}$ & $\mathrm{ND}$ & $\mathrm{ND}$ & $\mathrm{ND}$ & $\mathrm{ND}$ & $\mathrm{ND}$ & $\mathrm{ND}$ & $\mathrm{ND}$ \\
\hline $\mathrm{Pb}$ & 0.534 & 0.171 & 0.062 & 1.09 & 0.107 & 0.665 & 0.484 \\
\hline Type of material & $\mathrm{C}$ & $\mathrm{C}$ & $\mathrm{C}$ & $\mathrm{C}$ & $\mathrm{C}$ & $\mathrm{C}$ & $\mathrm{C}$ \\
\hline & & & & & & & \\
\hline
\end{tabular}




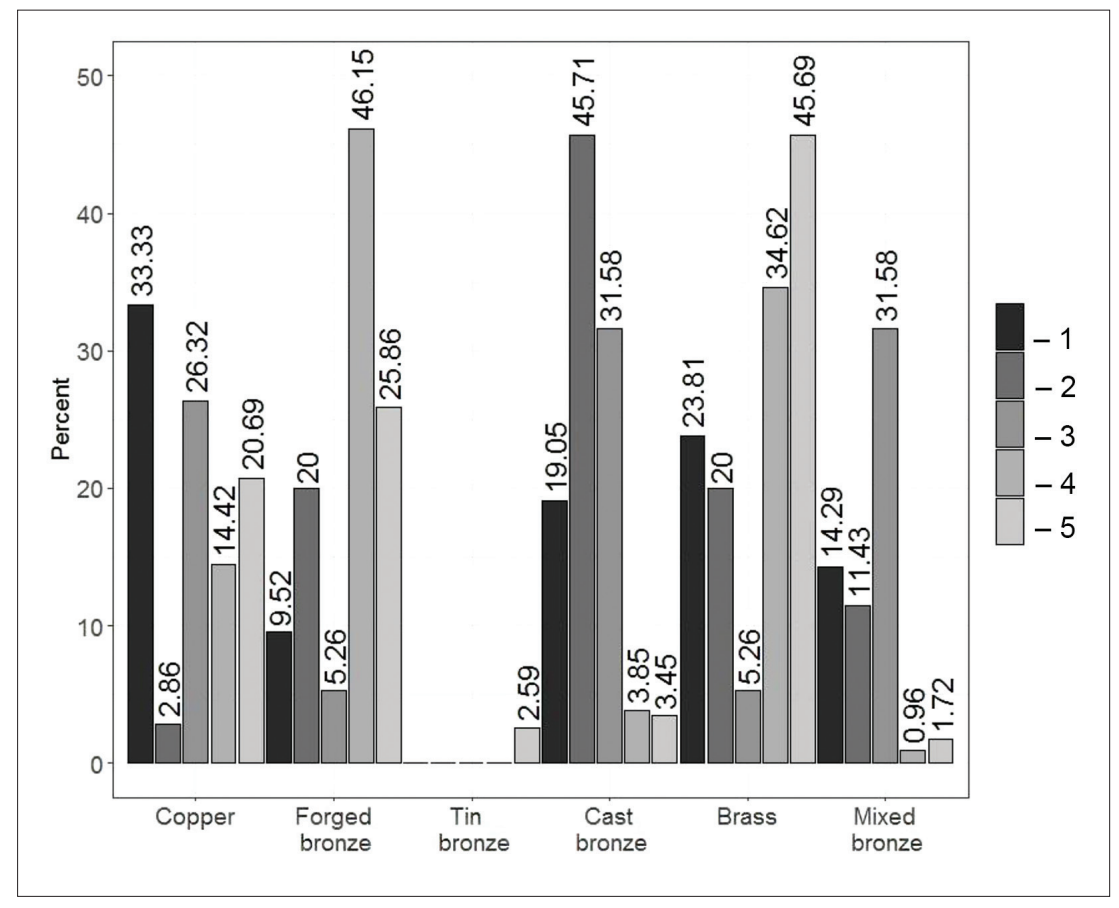

Figure 9. The distribution of fibulae by groups of manufacturing alloys.

1. Voitenki $1 ; 2$. Roman cast fibulae;

3. German cast fibulae; 4 . Roman forged fibulae; 5 . German forged fibulae.

For comparison, we used data in the literature (Voß et al., 1998) (IAP NAS of Ukraine, Sumy).

Table 2. The chemical composition of bronze fibulae (concentration in wt \%).

\begin{tabular}{|c|c|c|c|c|c|c|c|c|c|c|}
\hline & $\begin{array}{c}\text { Fibula } \\
84\end{array}$ & $\begin{array}{c}\text { Fibula } \\
77\end{array}$ & $\begin{array}{c}\text { Fibula } \\
88\end{array}$ & $\begin{array}{c}\text { Fibula } \\
69\end{array}$ & $\begin{array}{c}\text { Fibula } \\
70\end{array}$ & $\begin{array}{c}\text { Fibula } \\
86\end{array}$ & $\begin{array}{c}\text { Fibula } \\
74\end{array}$ & $\begin{array}{c}\text { Fibula } \\
81\end{array}$ & $\begin{array}{c}\text { Fibula } \\
89\end{array}$ & $\begin{array}{c}\text { Fibula } \\
79\end{array}$ \\
\hline $\mathrm{Al}$ & 1.312 & ND & 2.552 & 2.455 & 2.215 & 0.701 & ND & 0.579 & 1.745 & 21.499 \\
\hline $\mathrm{Cl}$ & ND & ND & $\mathrm{ND}$ & ND & $\mathrm{ND}$ & ND & ND & ND & ND & $\mathrm{ND}$ \\
\hline $\mathrm{K}$ & 0.148 & 0.061 & 0.467 & 0.755 & 0.041 & 0.045 & 0.495 & 0.048 & 0.422 & 4.421 \\
\hline $\mathrm{Ca}$ & 0.733 & 0.737 & 3.18 & 1.121 & 2.64 & 0.372 & 7.696 & 0.261 & 2.043 & 4.992 \\
\hline Sc & ND & $\mathrm{ND}$ & ND & $\mathrm{ND}$ & ND & 0.009 & ND & ND & ND & 0.069 \\
\hline $\mathrm{Ti}$ & 0.019 & 0.01 & 0.061 & 0.221 & 0.043 & 0.015 & 0.173 & 0.019 & 0.061 & 0.904 \\
\hline $\mathrm{V}$ & 0.009 & 0.012 & 0.079 & 0.063 & 0.131 & ND & 0.018 & 0.006 & 0.002 & 0.114 \\
\hline $\mathrm{Cr}$ & $\mathrm{ND}$ & $\mathrm{ND}$ & 0.006 & 0.017 & $\mathrm{ND}$ & 0.014 & 0.003 & 0.003 & 0.016 & 0.007 \\
\hline $\mathrm{Mn}$ & 0.008 & 0.003 & 0.013 & 0.023 & 0.004 & 0.01 & 0.546 & 0.006 & 0.008 & 0.079 \\
\hline $\mathrm{Fe}$ & 0.857 & 0.661 & 0.715 & 0.953 & 0.746 & 0.819 & 3.874 & 0.745 & 1.647 & 8.017 \\
\hline Co & 0.032 & ND & ND & ND & 0.001 & 0.012 & $\mathrm{ND}$ & $\mathrm{ND}$ & 0.023 & 0.059 \\
\hline $\mathrm{Ni}$ & 0.045 & 0.047 & 0.006 & 0.049 & $\mathrm{ND}$ & 0.001 & 0.067 & 0.005 & 0.072 & 0.005 \\
\hline $\mathrm{Cu}$ & 73.687 & 80.443 & 51.614 & 28.863 & 51.731 & 46.236 & 38.913 & 88.489 & 58.349 & 35.596 \\
\hline $\mathrm{Zn}$ & 6.968 & 4.221 & 0.478 & 0.497 & 0.193 & 3.6 & 8.680 & 3.505 & 16.243 & 0.582 \\
\hline As & 2.586 & 0.071 & 0.205 & $\mathrm{ND}$ & ND & ND & 0.252 & $\mathrm{ND}$ & 0.098 & 0.063 \\
\hline $\mathrm{Sr}$ & ND & 0.007 & ND & ND & ND & 0.035 & ND & ND & ND & 0.074 \\
\hline $\mathrm{Ag}$ & 0.43 & ND & $\mathrm{ND}$ & ND & ND & ND & ND & 0.173 & 0.21 & 0.044 \\
\hline $\mathrm{Cd}$ & 0.091 & ND & 0.211 & ND & ND & ND & $\mathrm{ND}$ & 0.022 & ND & $\mathrm{ND}$ \\
\hline Sn & 10.648 & 12.233 & 10.445 & 59.21 & 33.572 & 2.92 & 34.021 & 3.293 & 12.801 & 0.555 \\
\hline $\mathrm{Au}$ & $\mathrm{ND}$ & ND & ND & ND & 0.024 & $\mathrm{ND}$ & ND & ND & ND & ND \\
\hline $\mathrm{Pb}$ & 0.928 & 1.496 & 26.296 & 5.766 & 8.661 & 44.41 & 5.757 & 2.197 & 3.739 & 0.193 \\
\hline $\begin{array}{l}\text { Type of } \\
\text { material }\end{array}$ & $\mathrm{FB}$ & $\mathrm{FB}$ & $\mathrm{CB}$ & $\mathrm{CB}$ & $\mathrm{CB}$ & СВ & $\mathrm{MB}$ & $\mathrm{MB}$ & $\mathrm{MB}$ & MB (?) \\
\hline
\end{tabular}


Table 3. The chemical composition of brass fibulae (concentration in wt\%).

\begin{tabular}{|c|c|c|c|c|c|}
\hline & $\begin{array}{c}\text { Fibula } \\
82\end{array}$ & $\begin{array}{c}\text { Fibula } \\
83\end{array}$ & $\begin{array}{c}\text { Fibula } \\
85\end{array}$ & $\begin{array}{c}\text { Fibula } \\
71\end{array}$ & $\begin{array}{c}\text { Fibula } \\
72\end{array}$ \\
\hline A1 & 0.616 & 1.609 & 0.727 & ND & ND \\
\hline $\mathrm{C} 1$ & ND & ND & ND & 1.731 & 3.054 \\
\hline $\mathrm{K}$ & 0.31 & 0.154 & 0.054 & 0.182 & 0.247 \\
\hline $\mathrm{Ca}$ & 0.802 & 2.117 & 0.287 & 0.597 & 0.43 \\
\hline $\mathrm{Sc}$ & 0.014 & 0.043 & 0.011 & ND & ND \\
\hline $\mathrm{Ti}$ & 0.009 & 0.017 & 0.003 & 0.02 & 0.015 \\
\hline V & 0.032 & 0.044 & 0.002 & 0.003 & ND \\
\hline $\mathrm{Cr}$ & 0.028 & 0.023 & 0.003 & 0.003 & ND \\
\hline $\mathrm{Mn}$ & 0.022 & 0.019 & 0.008 & 0.005 & 0.009 \\
\hline $\mathrm{Fe}$ & 0.522 & 1.346 & 0.546 & 0.636 & 0.344 \\
\hline Co & 0.012 & 0.024 & 0.008 & 0.019 & 0.018 \\
\hline $\mathrm{Ni}$ & 0.006 & 0.095 & 0.07 & 0.019 & 0.27 \\
\hline $\mathrm{Cu}$ & 84.495 & 81.579 & 84.062 & 89.761 & 52.469 \\
\hline $\mathrm{Zn}$ & 11.285 & 7.527 & 10.699 & 5.754 & 39.472 \\
\hline As & 0.05 & ND & ND & ND & ND \\
\hline $\mathrm{Sr}$ & ND & ND & 0.018 & ND & ND \\
\hline $\mathrm{Ag}$ & 0.22 & ND & ND & ND & ND \\
\hline $\mathrm{Cd}$ & ND & 0.058 & ND & ND & ND \\
\hline Sn & 0.306 & 0.112 & 0.136 & ND & ND \\
\hline $\mathrm{Au}$ & $\mathrm{ND}$ & ND & ND & ND & 0.103 \\
\hline $\mathrm{Pb}$ & 0.329 & 2.839 & 2.585 & 0.969 & 1.287 \\
\hline e of & B & B & B & B & B \\
\hline
\end{tabular}

cast bronze group. Five specimens were brass fibulae, and their results are presented in Table 3. Only one sample of a brass fibula contained a silver admixture. Fibula 71 and the brass component of fibula 72 had no tin. Note that some fibulae had trace amounts of arsenic. It is quite difficult to identify the raw materials that delivered arsenic to the fibulae, as almost all sulphide ores of non-ferrous metals contain this admixture. This element, however, is a socalled 'fingerprint', and allows for the identification of raw sources and techniques of production. The large amount of light elements like aluminium, calcium, potassium, etc, present in the samples may have been conditioned by contaminants on the sample surface or by slag. Some fibulae had several components made of various metals, in other words, they contained several components of various materials (Table 4). Thus, in the above-mentioned fibula 72 , components of copper and tin were found, and a high concentration of iron was observed in the fibula spring. The springs of fibulae were often stabilised inside by an iron axis. Maybe fibula 72 also formerly had such an iron axis, the remains of which influenced the measuring result of the spring. Similarly, fibula 69 had the same 'button' and a component of cast bronze, and also the spring element, which could not be attributed to either of the groups, and consisted mainly of tin. In order to summarise the results of the chemical analysis, we have grouped the fibulae by the production material, and have compared them with the analysis results for forged and cast fibulae parts given in the works of German authors (Voß et al. 1998). For the quantities to be congruent, the results were recalculated as a percentage of the fibula of some material and presented in Figure 10. It should be noted that the distribution of fibula groups is similar to the distribution of cast German products (Voß et al. 1998, pp. 277-284). The only difference is in the fact that there is a larger amount of Voitenki brass fibulae, and fewer mixed bronze samples. It is quite the reverse for the cast German items.

Buckles. The next set of samples are presented by buckles, which may be divided into two groups: precious metals (characterised by a higher content of noble metals) (Table 5), and utilitarian (with a low concentration of noble metals) (Tables 6-8). A more detailed view of the precious samples showed that three of them were products based on bronze alloys with silver admixtures (samples 92, 93, 96). Sample 111 was, however, made of silver with a $5 \mathrm{wt} \%$ admixture of copper. The analysis results of 'utilitarian' buckles (characterised by the low content of noble metals) allowed for their division into three groups, similar to fibulae. Buckles made of copper with small weight fractions of $\mathrm{Zn}, \mathrm{Sn}, \mathrm{Pb}$ (Table 6) are the first group. As in the case of fibulae, the alloy of the buckles is difficult to identify. Low concentrations of silver, up to $0.7 \mathrm{wt} \%$, were also found in some samples. The utilitarian buckle group comprised bronze and brass buckles (Table 7), with the bronze ones belonging to the cast bronze group, which identifies their production technique. Arsenic was found in all the samples here.

Samples of precious metal alloys. The set of samples to be studied included precious metal products as well. The analysis results from these samples are presented in Tables 5 and 8 . Based on the results, it is evident that the products were made from silver of high quality. Sample 109 alone contained a concentration of copper over $10 \mathrm{wt} \%$. All the samples had gold and lead in small amounts (less than 1\%). About $0.03 \mathrm{wt} . \%$ of arsenic was presented in three samples, 109, 110 and 112, which may indicate the use of non-ferrous metals extracted from sulphide ores as dopants and using techniques not involving cleaning the 
Table 4. The chemical composition of fibulae and their components (concentration in wt\%).

\begin{tabular}{|c|c|c|c|c|c|c|c|c|c|c|}
\hline & $\begin{array}{l}69, \\
\text { rod of } \\
\text { spring }\end{array}$ & $\begin{array}{c}69, \\
\text { spring } 1\end{array}$ & $\begin{array}{c}69, \\
\text { spring } 2\end{array}$ & 69, body & $\begin{array}{c}72, \\
\text { spring } 1\end{array}$ & $\begin{array}{c}72, \\
\text { spring } 2\end{array}$ & $\begin{array}{c}72, \\
\text { body } 1\end{array}$ & $\begin{array}{c}72, \\
\text { body } 2\end{array}$ & $\begin{array}{c}72, \\
\text { body } 3\end{array}$ & $\begin{array}{c}72, \\
\text { body } 4\end{array}$ \\
\hline $\mathrm{Cl}$ & 1.736 & 2.611 & 2.849 & 2.455 & 3.703 & 2.961 & 2.190 & 1.820 & 1.572 & 3.054 \\
\hline $\mathrm{K}$ & 0.35 & 0.101 & 0.258 & 0.755 & 0.514 & 0.432 & 0.228 & 0.366 & 0.336 & 0.247 \\
\hline $\mathrm{Ca}$ & 1.190 & 2.458 & 1.646 & 1.121 & 1.358 & 3.669 & 0.322 & 0.577 & 0.639 & 0.430 \\
\hline $\mathrm{Ti}$ & 0.231 & 0.185 & 0.079 & 0.221 & 0.080 & 0.072 & 0.010 & 0.018 & 0.030 & 0.015 \\
\hline $\mathrm{V}$ & 0.007 & 0.086 & $\mathrm{ND}$ & 0.063 & 0.013 & $\mathrm{ND}$ & 0.004 & 0.009 & 0.005 & $\mathrm{ND}$ \\
\hline $\mathrm{Cr}$ & 0.003 & 0.006 & ND & 0.017 & $\mathrm{ND}$ & ND & $\mathrm{ND}$ & $\mathrm{ND}$ & 0.003 & ND \\
\hline $\mathrm{Mn}$ & 0.020 & 0.017 & 0.015 & 0.023 & 0.022 & 0.029 & ND & 0.005 & 0.006 & 0.009 \\
\hline $\mathrm{Fe}$ & 0.451 & 4.312 & 39.894 & 0.953 & 37.802 & 29.988 & 0.301 & 0.328 & 0.352 & 0.344 \\
\hline Co & $\mathrm{ND}$ & $\mathrm{ND}$ & ND & $\mathrm{ND}$ & ND & ND & 0.009 & 0.009 & 0.005 & 0.018 \\
\hline $\mathrm{Ni}$ & 0.057 & 0.059 & 0.045 & 0.049 & 0.150 & 0.186 & 0.024 & 0.058 & 0.109 & 0.270 \\
\hline $\mathrm{Cu}$ & 2.266 & 27.781 & 21.704 & 28.863 & 44.689 & 37.464 & 91.6 & 81.422 & 73.943 & 52.469 \\
\hline $\mathrm{Zn}$ & 0.282 & 0.383 & 0.260 & 0.497 & 9.420 & 19.229 & 2.621 & 11.519 & 18.975 & 39.472 \\
\hline $\mathrm{Ag}$ & $\mathrm{ND}$ & $\mathrm{ND}$ & $\mathrm{ND}$ & $\mathrm{ND}$ & ND & 0.075 & $\mathrm{ND}$ & ND & ND & ND \\
\hline Sn & 40.709 & 55.975 & 30.836 & 59.21 & 0.284 & 0.068 & ND & ND & ND & ND \\
\hline $\mathrm{Au}$ & 0.053 & 0.031 & ND & $\mathrm{ND}$ & $\mathrm{ND}$ & 0.180 & $\mathrm{ND}$ & 0.055 & $\mathrm{ND}$ & 0.103 \\
\hline $\mathrm{Pb}$ & 2.266 & 5.991 & 2.277 & 5.766 & 1.403 & 2.005 & 0.484 & 1.078 & 1.442 & 1.287 \\
\hline
\end{tabular}

Abbreviations: $\mathrm{C}$ copper, $\mathrm{FB}$ forged bronze, $\mathrm{CB}$ cast bronze, $\mathrm{MB}$ mixed bronze, $\mathrm{B}$ brass, ND not detected.

alloy. It is entirely possible that these products were made of secondary raw materials and/or Roman coins. In this case, arsenic migrates from product to product as an admixture. The element concentration ranges typical of silver Roman coins and their barbarian imitations are given in Table 6. The concentrations of the elements studied fit mainly into these ranges. It is worth noting that the products are free of elements such as mercury and iodine, identified during coin analysis. This should come as no surprise, since these elements could be used as precious metal references for a coin in regular rotation. On being heated, these elements are stripped, and mercury and iodine are not observed in the silver products. Considering that these products are not grouped separately during the principal component analysis, and that there are no key differences in the chemical composition as compared to the silver Roman coins and their barbarian counterfeits, the assumption of coins used as raw materials should not be excluded.

\section{Discussion}

The analyses presented offer abundant information concerning the composition of metal. The following conclusions or even hypotheses are limited by the small number of objects under consideration. Furthermore, the analyses were conducted without the special preparation of the objects, so some pollution or corrosion on the surface has to be taken into account.

For the brooches, the groups of chemical composition are connected with different archaeological types: copper as a basic material was detected first of all in crossbow tendril brooches (Fig. 2.73, 75, 76, 78), and in one crossbow fibula with a closed catch-plate (Fig. 2.80); and further in one brooch with a high catch-plate, which differs in noticeable traces of silver (Fig. 2.87).

The bronze brooches can be divided into subgroups. There is a group of forged bronze items represented by 
Table 5. The elemental composition of 'noble' buckles (characterised by the higher content of noble metals) (concentration in wt\%).

\begin{tabular}{|c|c|c|c|c|}
\hline & $\begin{array}{c}\text { Buckle } \\
\mathbf{9 2}\end{array}$ & $\begin{array}{c}\text { Buckle } \\
\mathbf{9 3}\end{array}$ & Buckle 96 & $\begin{array}{c}\text { Buckle 111 } \\
\text { (white metal) }\end{array}$ \\
\hline $\mathrm{Al}$ & 2.378 & 2.23 & 1.614 & 1.244 \\
\hline $\mathrm{Cl}$ & 0.719 & 0.244 & 0.11 & $\mathrm{ND}$ \\
\hline $\mathrm{K}$ & 0.251 & 0.097 & 0.047 & $\mathrm{ND}$ \\
\hline $\mathrm{Ca}$ & 3.522 & 0.508 & 0.469 & 0.086 \\
\hline $\mathrm{Sc}$ & 0.035 & $\mathrm{ND}$ & $\mathrm{ND}$ & $\mathrm{ND}$ \\
\hline $\mathrm{Ti}$ & 0.059 & 0.031 & 0.04 & 0.003 \\
\hline $\mathrm{V}$ & $\mathrm{ND}$ & $\mathrm{ND}$ & 0.104 & 0.001 \\
\hline $\mathrm{Cr}$ & 0.003 & 0.009 & 0.002 & 0.189 \\
\hline $\mathrm{Mn}$ & 0.129 & 0.004 & $\mathrm{ND}$ & 0.001 \\
\hline $\mathrm{Fe}$ & 1.467 & 0.759 & 1.424 & 0.048 \\
\hline $\mathrm{Co}$ & 0.024 & 0.013 & 0.022 & 0.004 \\
\hline $\mathrm{Ni}$ & 0.164 & 0.049 & 0.037 & 0.000 \\
\hline $\mathrm{Cu}$ & 23.213 & 72.824 & 34.091 & 5.031 \\
\hline $\mathrm{Zn}$ & 6.813 & 1.593 & 1.66 & 0.03 \\
\hline $\mathrm{As}$ & 0.419 & 0.253 & 0.252 & 0.013 \\
\hline $\mathrm{Sr}$ & 0.057 & $\mathrm{ND}$ & 0.027 & 0.014 \\
\hline $\mathrm{Ag}$ & 10.299 & 3.001 & 8.306 & 91.346 \\
\hline $\mathrm{Cd}$ & 0.846 & 0.000 & 0.215 & 0.000 \\
\hline $\mathrm{Sn}$ & 38.699 & 12.946 & 33.703 & 0.094 \\
\hline $\mathrm{Ba}$ & 0.048 & $\mathrm{ND}$ & $\mathrm{ND}$ & 0.002 \\
\hline $\mathrm{Au}$ & $\mathrm{ND}$ & $\mathrm{ND}$ & $\mathrm{ND}$ & 0.502 \\
\hline $\mathrm{Pb}$ & 7.235 & 3.206 & 16.222 & 0.224 \\
\hline & & & & \\
\hline
\end{tabular}

one crossbow fibula with a closed catch-plate (Fig. 2.84), and one crossbow tendril brooch (Fig. 2.77). The Bügelknopffibel (Fig. 2.88) and one brooch with a high catchplate (Fig. 2.86) were produced from cast bronze. For both these types, the material suits the cast as the manufacturing technique of these brooches. But two crossbow tendril brooches (Fig. 2.69, 70) were also made of cast bronze, although they were manufactured by forging. Two crossbow brooches with a closed catch-plate (Fig. 2.79, 81) and a fibula with elements of a sheet brooch and a knop bow fibula (Fig. 2.89) consist of mixed bronze.

Brass as a basic material was detected for at least four brooches: three with a closed catch-plate (Fig. 2.82, 83,
85), crossbow tendril brooch No 71, and a part of No 72 (see Table 3).

Special attention should be paid to the three crossbow tendril brooches from grave 129 (Fig. 2.71-73). These fibulae differ in their material: No 71 was made of brass, and Nos 72 and 73 were made of copper (see Tables 1;3). As was mentioned above, fibulae Nos 72 and 73 are twin brooches, nearly identical in their form and design. Therefore, we can assume that they were produced at the same time, and that the same material was applied. According to the analyses, there is no total coincidence concerning the metal of both brooches (Table 1). But taking into account the minimal preparation of the samples, the presence of contamination, and corrosion, it is impossible to say that these fibulae are made from different materials. The material is similar in composition. Detailed analyses showed that fibula No 72 consisted of brass, copper and other components, even in parts like the bow (Table 4). It is likely that mixed material was used for producing this brooch. But it is an open question how these pieces of quite different material were connected during manufacture.

\section{Conclusions}

Summing up the results, there are hardly connections detectable between the different compositions of the material and the types of brooches. As a preliminary conclusion, it can just be emphasised that the cast brooches in particular were manufactured from cast bronze. On the other hand, it seems that the producer used the material that was available, for example cast bronze for forged brooches. Furthermore, they used mixed materials, and combined pieces of different composition. The manufacture of copper brooches also seems to be a 'less than ideal' solution, because copper without alloying elements is more flexible, and softness is a disadvantage for a fastener for clothes.

The buckles also consisted of different material; besides copper, cast bronze and brass, bronze composition with silver was detected. This precious metal seems to have been added consciously. One small thickened ring (Fig. 4.111) was made of silver, and could represent the frame of a buckle. There were no buckles with a composition of several pieces or mixed materials. But as for the brooches, there is no connection between the form of the buckle and the material. Oval buckles with a thickened frame, similar in size and design, can be made of copper (Fig. 4.91), bronze with silver (Fig. 4.96), or brass (Fig. 4.97). The number of buckles with other forms is too limited for further conclusions. The diversity of material for buckles with a thickened frame suggests that the material selected for manufacture may have been regulated by the resources available. 
Table 6. The elemental composition of 'utilitarian' copper buckles (concentration in $\mathrm{wt} \%)$.

\begin{tabular}{|c|c|c|c|c|c|c|c|c|c|}
\hline & $\mathbf{9 0}$ & $\mathbf{9 1}$ & $\mathbf{9 5}$ & $\mathbf{9 8}$ & $\mathbf{1 0 0}$ & $\mathbf{1 0 2}$ & $\mathbf{1 0 3}$ & $\mathbf{1 0 5}$ & $\mathbf{1 0 6}$ \\
\hline $\mathrm{Al}$ & 5.873 & 0.841 & $\mathbf{1 . 6 0 3}$ & 0.779 & 6.794 & 0.942 & 10.021 & 0.253 & 0.715 \\
\hline $\mathrm{Cl}$ & $\mathrm{ND}$ & $\mathrm{ND}$ & 0.234 & 0.472 & 0.803 & $\mathrm{ND}$ & $\mathrm{ND}$ & $\mathrm{ND}$ & 0.14 \\
\hline $\mathrm{K}$ & 0.751 & 0.094 & 0.42 & 0.139 & 1.000 & 0.863 & 1.486 & 0.011 & 0.074 \\
\hline $\mathrm{Ca}$ & 1.582 & 0.201 & 0.922 & 0.809 & 2.468 & 1.511 & 1.942 & 0.456 & 0.236 \\
\hline $\mathrm{Sc}$ & 0.018 & $\mathrm{ND}$ & 0.004 & 0.01 & 0.045 & 0.021 & 0.041 & 0.014 & 0.014 \\
\hline $\mathrm{Ti}$ & 0.127 & 0.004 & 0.022 & 0.013 & 0.35 & 0.028 & 0.34 & 0.001 & $\mathrm{ND}$ \\
\hline $\mathrm{V}$ & 0.011 & 0.005 & 0.011 & 0.01 & 0.164 & 0.021 & 0.007 & 0.003 & 0.012 \\
\hline $\mathrm{Cr}$ & 0.004 & $\mathrm{ND}$ & $\mathrm{ND}$ & 0.006 & 0.015 & 0.157 & $\mathrm{ND}$ & 0.006 & 0.001 \\
\hline $\mathrm{Mn}$ & 0.017 & 0.003 & 0.002 & 0.007 & 0.013 & 0.032 & 0.021 & 0.006 & $\mathrm{ND}$ \\
\hline $\mathrm{Fe}$ & 0.965 & 0.239 & 0.303 & 0.882 & 3.325 & 2.54 & 2.251 & 0.756 & 0.295 \\
\hline $\mathrm{Co}$ & 0.01 & 0.005 & 0.003 & 0.008 & 0.024 & 0.029 & 0.011 & 0.018 & 0.005 \\
\hline $\mathrm{Ni}$ & 0.009 & 0.087 & 0.024 & 0.062 & 0.062 & 0.005 & 0.003 & 0.019 & $\mathrm{ND}$ \\
\hline $\mathrm{Cu}$ & 83.645 & 95.03 & 88.435 & 90.532 & 72.398 & 89.173 & 71.098 & 93.254 & 94.807 \\
\hline $\mathrm{Zn}$ & 0.283 & 0.237 & 0.365 & 0.987 & 2.457 & 1.817 & 1.172 & 3.94 & 0.999 \\
\hline $\mathrm{As}$ & 0.075 & 0.447 & 0.252 & 0.292 & 0.157 & 0.109 & 0.201 & 0.032 & 0.045 \\
\hline $\mathrm{Ag}$ & $\mathrm{ND}$ & $\mathrm{ND}$ & 0.458 & 0.709 & $\mathrm{ND}$ & 0.052 & 0.048 & 0.169 & 0.029 \\
\hline $\mathrm{Cd}$ & $\mathrm{ND}$ & $\mathrm{ND}$ & 0.058 & 0.025 & $\mathrm{ND}$ & $\mathrm{ND}$ & $\mathrm{ND}$ & $\mathrm{ND}$ & 0.058 \\
\hline $\mathrm{Sn}$ & 0.238 & 1.73 & 1.663 & 1.716 & 0.253 & 0.719 & 0.403 & 0.517 & 1.703 \\
\hline $\mathrm{Ba}$ & 0.012 & 0.014 & 0.024 & $\mathrm{ND}$ & 0.012 & $\mathrm{ND}$ & $\mathrm{ND}$ & $\mathrm{ND}$ & $\mathrm{ND}$ \\
\hline $\mathrm{Pb}$ & 0.244 & 0.189 & 3.255 & 1.485 & 2.126 & 0.316 & 0.693 & 0.114 & 0.107 \\
\hline $\mathrm{Type}$ of & $\mathrm{C}$ & $\mathrm{C}$ & $\mathrm{C}$ & $\mathrm{C}$ & $\mathrm{C}$ & $\mathrm{C}$ & $\mathrm{C}$ & $\mathrm{C}$ & $\mathrm{C}$ \\
$\mathrm{material}$ & $\mathrm{C}$ & & & & & & & \\
\hline
\end{tabular}

Abbreviations: C copper.

Table 7. The elemental composition of 'utilitarian' bronze and brass buckles (concentration in wt\%).

\begin{tabular}{|c|c|c|c|c|c|}
\hline & $\mathbf{9 4}$ & $\mathbf{1 0 1}$ & $\mathbf{1 0 4}$ & $\mathbf{9 7}$ & $\mathbf{9 9}$ \\
\hline $\mathrm{Al}$ & 2.051 & 1.078 & 1.048 & 0.905 & 0.825 \\
\hline $\mathrm{C} 1$ & 0.924 & 0.568 & N.B. & 0.334 & 1.384 \\
\hline $\mathrm{K}$ & 0.262 & 0.408 & 0.249 & 0.151 & 0.191 \\
\hline $\mathrm{Ca}$ & 1.977 & 0.693 & 0.644 & 0.278 & 0.349 \\
\hline $\mathrm{Sc}$ & 0.007 & N.B. & N.B. & N.B. & 0.015 \\
\hline $\mathrm{Ti}$ & 0.033 & 0.031 & 0.018 & 0.017 & 0.005 \\
\hline $\mathrm{V}$ & 0.051 & N.B. & 0.01 & N.B. & 0.009 \\
\hline $\mathrm{Cr}$ & $\mathrm{N} . \mathrm{B}$. & 0.003 & 0.003 & 0.001 & 0.003 \\
\hline $\mathrm{Mn}$ & 0.015 & 0.001 & N.B. & 0.005 & 0.01 \\
\hline $\mathrm{Fe}$ & 1.326 & 0.311 & 0.348 & 1.062 & 0.317 \\
\hline $\mathrm{Co}$ & 0.01 & 0.005 & 0.014 & 0.06 & 0.009 \\
\hline $\mathrm{Ni}$ & 0.017 & N.B. & 0.17 & 0.063 & 0.005 \\
\hline $\mathrm{Cu}$ & 42.697 & 43.169 & 73.536 & 88.527 & 86.295 \\
\hline $\mathrm{Zn}$ & 1.048 & 0.223 & 1.884 & 7.314 & 6.579 \\
\hline
\end{tabular}




\begin{tabular}{|c|c|c|c|c|c|}
\hline & $\mathbf{9 4}$ & $\mathbf{1 0 1}$ & $\mathbf{1 0 4}$ & $\mathbf{9 7}$ & $\mathbf{9 9}$ \\
\hline $\mathrm{As}$ & 0.208 & 0.073 & 0.265 & 0.049 & 0.341 \\
\hline $\mathrm{Ag}$ & 0.58 & 0.203 & 0.124 & 0.017 & N.B. \\
\hline $\mathrm{Cd}$ & N.B. & N.B. & 0.389 & N.B. & N.B. \\
\hline $\mathrm{Sn}$ & 23.085 & 4.626 & 8.32 & 0.123 & 1.298 \\
\hline $\mathrm{Ba}$ & N.B. & N.B. & N.B. & 0.003 & 0.005 \\
\hline $\mathrm{Pb}$ & 23.009 & 47.254 & 11.713 & 0.109 & 1.434 \\
\hline $\begin{array}{c}\text { Type of } \\
\text { mate- } \\
\text { rial - }\end{array}$ & $\mathrm{CB}$ & $\mathrm{CB}$ & $\mathrm{CB}$ & $\mathrm{B}$ & $\mathrm{B}$ \\
\hline
\end{tabular}

Abbreviations: $\mathrm{CB}$ cast bronze, $\mathrm{B}$ brass.

Table 8. The elemental composition of noble metal items (concentration in wt\%).

\begin{tabular}{|c|c|c|c|c|c|c|}
\hline & 107 & 108 & 109 & 110 & 112 & Typical concentration ranges for silver coins \\
\hline A1 & 1.602 & 0.899 & 1.774 & 2.041 & 1.878 & - \\
\hline $\mathrm{C} 1$ & 0.000 & 0.153 & 0.674 & 0.000 & 0.202 & - \\
\hline K & 0.000 & 0.000 & 0.000 & 0.000 & 0.000 & 0.000 \\
\hline $\mathrm{Ca}$ & 0.141 & 0.513 & 0.281 & 0.161 & 0.136 & $0.051-1.7$ \\
\hline Sc & 0.003 & 0.000 & 0.000 & 0.000 & 0.005 & $0-0.034$ \\
\hline $\mathrm{Ti}$ & 0.013 & 0.021 & 0.016 & 0.002 & 0.005 & $0-0.17$ \\
\hline $\mathrm{V}$ & 0.000 & 0.000 & 0.000 & 0.002 & 0.006 & $0-0.026$ \\
\hline Сг & 0.001 & 0.343 & 0.000 & 0.003 & 0.129 & $0-0.059$ \\
\hline $\mathrm{Mn}$ & 0.000 & 0.002 & 0.001 & 0.002 & 0.000 & $0-0.038$ \\
\hline $\mathrm{Fe}$ & 0.077 & 0.305 & 0.058 & 0.066 & 0.046 & $0.008-2$ \\
\hline Co & 0.004 & 0.004 & 0.000 & 0.004 & 0.000 & $0-0.258$ \\
\hline $\mathrm{Ni}$ & 0.000 & 0.031 & 0.000 & 0.007 & 0.007 & $0-0.01$ \\
\hline $\mathrm{Cu}$ & 2.299 & 4.422 & 14.273 & 7.002 & 4.482 & $0.375-19.4$ \\
\hline $\mathrm{Zn}$ & 0.013 & 1.098 & 0.087 & 3.126 & 0.015 & $0.006-1.5$ \\
\hline As & 0.000 & 0.000 & 0.030 & 0.038 & 0.028 & $0-0.05$ \\
\hline $\mathrm{Sr}$ & 0.020 & 0.000 & 0.000 & 0.000 & 0.000 & 0.000 \\
\hline $\mathrm{Ag}$ & 94.236 & 89.169 & 79.306 & 84.880 & 90.543 & $76.39-97.29$ \\
\hline $\mathrm{Cd}$ & 0.000 & 0.000 & 0.000 & 0.000 & 0.000 & 0.000 \\
\hline Sn & 0.000 & 1.006 & 0.414 & 0.011 & 0.082 & $0-6.29$ \\
\hline $\mathrm{Ba}$ & 0.000 & 0.015 & 0.000 & 0.000 & 0.005 & 0.000 \\
\hline $\mathrm{Au}$ & 0.059 & 0.788 & 0.983 & 0.484 & 0.477 & $0.222-1.34$ \\
\hline $\mathrm{Pb}$ & 0.059 & 0.243 & 0.422 & 0.318 & 0.277 & $0.006-1.18$ \\
\hline
\end{tabular}


All analyses of non-ferrous metal objects showed quite different compositions of bronze and brass. But no specific mixture came to light for certain types of item, and there is no specific composition of metal which was detected as characteristic of the site at Voitenki.

The 'white metal' was determined as silver of high quality. Analogies with objects of almost pure silver are rarely proven in Cherniakhov culture. They have been detected for finds from cemeteries at Kurniki, Kantemirovka, Kosanovo and Budeshty. The comparison of silver finds from Voitenki with silver of Roman denarii leads to the hypothesis that these coins were used as raw material for manufacturing the considered objects.

Conclusions concerning the extent and quality of metal working are quite difficult, due to the limited number of analyses. The examined finds were probably produced by craftsmen of Cherniakhov culture, but there is no evidence for their manufacture in the settlement at Voitenki. At the moment, the level of local metal working is still unknown. In general, the reuse of metal from the Roman Empire was conducted successfully. The technical skills for recycling different non-ferrous metal, alloys and compositions are visible in the objects produced. Special knowledge was detected to use cast bronze for casting brooches. The experience of metal-working was based on the influx of Roman metal artefacts like vessels, weapons, tools, coins, and others. This influx was not regular, but depended on relations, warlike operations (loot), or opportunities for exchange. Due to this imponderability, metalworkers in Cherniakhov culture were faced with variable 'raw material', which required the development of their skills.

\section{References}

Almgren, O., 1923. Studien über Nordeuropäische Fibelformen der ersten nachchristlichen Jahrhunderte mit Berücksichtigung der provinzialrömischen und südrussischen Formen. MannusBibliothek 32, 2nd ed. Leipzig: Curt Kabitzsch.

Becker, M., 2010. Das Fürstengrab von Gommern. Veröffentlichungen des Landesamtes für Archäologie 63. Landesamt für Denkmalpflege und Archäologie Sachsen-Anhalt, Landesmuseum für Vorgeschichte, Halle: Landesamt für Denkmalpflege und Archäologie Sachsen-Anhalt, Landesmuseum für Vorgeschichte.

Buhay, O.M., Drozdenko, A.A., Zakharets, M.I., Ignat'ev, I.G., Kramchenkov, A.B., Miroshnichenko, V.I., Ponomarev, A.G., Storizhko, V.E., 2015. Current Status of the IAP NASU Accelerator-Based Analytical Facility. Physics Procedia, 66, 164-176.

Bursche, A., Myzgin, K., 2017. K voprosu o tekhnologii proizvodstva rannikh varvarskikh podrzhaniı̌ rimskim monetam (po rezul'tatam metallograficheskikh analizov). In: Numizmaticheskie chteniia gosudarstvennovo istoricheskovo muzeia 2017 god. Moscow, pp. 404-43.

Campbell, J.L., Hopman, T.L., Maxwel, J.A., Nejedly, Z., 2000. The Guelph PIXE software package III: Alternative proton database. NIMB (Nuclear Instruments and Methods in
Physics Research Section B: Beam Interactions with Materials and Atoms), 170, 193-204.

Chernykh, E. A., Bartseva, T.B., 1970. Spektroanaliticheskie issledovania tsvetnovo metalla cherniakhovskoi kul'tury. Kratkie soobshchenia instituta arkheologii, 121, 95-103.

Gereta, I.P., 2016. Chernelevo-Rus'kil mogil'nik. Oium 3. Kiev: Ternopil'.

Gorokhovskiū, Ė.L., 1989 Khronologia cherniakhovskikh mogil'nikov Lesostepnoŭ Ukrainy. In: Trudy V Mezhdunarodnovo Kongresa Arkheologov-Slavistov, 4. Kiev: Naukova dumka, pp. 36-46.

Liubichev, M. V., Buhay, A. N., Schultze, Ė., 2020. Estestvennonauchnye issledovania metallicheskikh izdeliǐ pozdnerimskogo vremeni: pervye resultaty analiza nakhodok iz Vortenkov (vostochnaia Ukraina). In: M. Liubichev, K. Myzgin, eds. Inter Orientem et Occidentem. Ostrogothica-Serie: Bände 3. Kharkiv: KhNU imeni W.N. Karazina, pp. 479-501.

Madyda-Legutko, R., 1987. Die Gürtelschnallen der römischen Kaiserzeit und der frühen Völkerwanderungszeit im mitteleuropäischen Barbaricum. In: BAR British Archaeological Reports. International Series 360. Oxford: Great Britain.

Magomedov, B.V., 1999. Cherniakhovskiĭ mogil'nik Kurniki na Iuzhnom Buge. Stratum plus, 4, 102-120.

Magomedov, B.V., 2001. Cherniakhovskaia kul'tura. Problema etnosa. Lublin: Wydawnictwo Uniwersitetu Marii CurieSkłodowskiej.

Schultze, E., Liubichev, M.V., 2020. Silver fittings of a vessel from a Late Roman burial of the Chernyakhov culture in Voitenki.

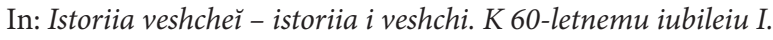
O. Gavritukhina. Ranneslavianskiĭ Mir 20. Moscow: IA RAN, pp. 147-156.

Voß, H.-U., Hammer, P., Lutz J., 1998. Römische und germanische Bunt- und Edelmetallfunde im Vergleich. Archäometallurgische Untersuchungen ausgehend von elbgermanischen Körpergräbern. Bericht der Römisch-Germanischen Kommission, $79,107-382$.

\section{NEDESTRUKT Y VINIAI \\ VOITENKI KAPINYNO VARIO \\ LYDINIŲ IR SIDABRO \\ TYRIMAI. METALO \\ PERDIRBIMAS ČERNIACHOVO \\ KULTÜROJE}

\section{MIKHAIL V. LIUBICHEV, OLEKSANDR M. BUHAY, ERDMUTE SCHULTZE}

\section{Santrauka}

Segès, diržo sagtys ir kiti specifinio dizaino metaliniai daiktai laikomi Černiachovo kultūros bruožais. Šių dirbinių tipologija gerai žinoma, priešingai nei jų metalo sudètis, kuri buvo retai tiriama. Norint daugiau sužinoti apie bendrą Černiachovo kultūros metalo apdirbimo lygi, metalo sudèties analizei buvo pasirinkti 44 artefaktai, aptikti Voitenki (Rytų Ukraina) gyvenvietėje ir kapinyne 
(1 pav.). Tyrimams pasirinktos kelių tipų lankinės ir kitų tipų segès bei ovalios, storesne priekine dalimi diržų sagtys (2, 3 pav.).

Iš viso 38 dirbiniai buvo pagaminti iš vario lydinių, šeši iš sidabro. Tiksli metalo sudètis buvo tirta atliekant PIXE (sužadintųjų dalelių sukelta rentgeno spinduliuotè) analizę (5-7 pav.; 1-8 lentelès). Šiuo metodu nustatyta, kad tirtos segès ir sagtys gamintos iš bronzos ir žalvario. Bronzos lydiniai suskirstyti ị kaltinę bronzą ir lietą bronzą, be to, aptikta mišrios sudèties vario lydinių. Tačiau šios metalo grupès ir pogrupiai nesutampa su archeologiniais tipais. Lankinès segès gamintos iš vario, nors kai kurios iš jų buvo pagamintos iš bronzos arba žalvario. Lieta bronza buvo naudojama kai kurių rūšių segèms gaminti. Amatininkai sąmoningai pasirinko lietą bronzą lietoms segėms gaminti. Tačiau, kita vertus, atrodo, kad amatininkai naudojo tokią medžiagą, kokia buvo prieinama, pavyzdžiui, lieta bronza buvo naudota kaltinėms segèms gaminti (8 pav.). Sagtys taip pat pagamintos iš įvairių vario lydinių, be lietos bronzos ir žalvario, buvo nustatyta bronza, kurioje yra sidabro. Nèra aiškaus ryšio tarp sagčių iš vario lydinio ir jų formos ar tipo. Šešiose sagtyse PIXE analizė nustatė dideli sidabro kiekį. Palyginus rezultatus su roméniškojo laikotarpio sidabro denarų analize, galima daryti prielaidą, kad tokios Romos monetos buvo naudojamos kaip „žaliava“ tirtiems sidabro dirbiniams gaminti. 